\title{
Gibbs Energy Modeling of the Cu-S Liquid Phase: Completion of the Thermodynamic Calculation of the Cu-S System
}

\begin{abstract}
PETER WALDNER
A thorough review and critical evaluation of all experimental sulfur potential and phase diagram data available from the literature has been made for optimizing the Gibbs energy of the copper-sulfur liquid phase at 1 bar total pressure. The extended modified quasichemical model serves as a basis for the mathematical expression of the Gibbs energy of binary $\mathrm{Cu}-\mathrm{S}$ solutions over the complete composition range. A structurally versatile molten phase ranging from highly metallic via sulfur-rich to pure sulfuric is described simultaneously by a single Gibbs energy function. In combination with the recently published Gibbs energies of all $\mathrm{Cu}-\mathrm{S}$ solid phases, the complete $T-x$ phase diagram as well as for the first time the $\log \left(p_{\mathrm{S} 2} /\right.$ bar $)-1 / T$ diagram is calculated. A limited set of obtained model parameters reproduces a large body of data within experimental uncertainties.
\end{abstract}

https://doi.org/10.1007/s11663-020-01796-x

(c) The Author(s) 2020

\section{INTRODUCTION}

THE liquid phase of the copper-sulfur system is characterized by the existence of two extended regions of miscibility gaps between them the solid solution digenite melts congruently at a stoichiometry around $\mathrm{Cu}_{2} \mathrm{~S}$. According to the review of Chakrabarti and Laughlin ${ }^{[1]}$ the liquidus maximizes at $1403 \pm 2 \mathrm{~K}(1130$ $\pm 2{ }^{\circ} \mathrm{C}$ ) in relation with the congruent melting point of digenite while the liquid solution demixes within two miscibility gaps above $1378 \mathrm{~K}\left(1105^{\circ} \mathrm{C}\right)$ at copper-rich compositions on one side of digenite and above $1086 \mathrm{~K}$ $\left(813^{\circ} \mathrm{C}\right)$ at higher sulfur compositions on the other side. Including the melt, nine condensed $\mathrm{Cu}-\mathrm{S}$ phases are reported for 1 bar total pressure, which are the solids anilite $\mathrm{Cu}_{1.75} \mathrm{~S}$, covellite $\mathrm{CuS}$, high- and low-temperature chalcocite, djurleite, digenite and the terminal phases based on $\mathrm{Cu}$ and $\mathrm{S}$.

Thermodynamic modeling studies on the copper-sulfur melts were the subject of several studies such as those of Kellogg ${ }^{[2,3]}$ and Larrain et al. ${ }^{[4]}$ using an associate solution description. Sharma and Chang ${ }^{[5]}$ took into account the same approach for the liquid solution and additionally considered covellite, high-temperature chalcocite and digenite for a thermodynamic analysis of the

PETER WALDNER is with the Department of General, Analytical and Physical Chemistry, University of Leoben, Franz-Josef-StraÔe 18, 8700 Leoben, Austria. Contact e-mail: peter.waldner@unileoben.ac.at Manuscript submitted November 6, 2019.

Article published online February 20, 2020.
$\mathrm{Cu}-\mathrm{S}$ system. Dinsdale et al. $^{[6]}$ published a partial assessment of the copper-sulfur system regarding a two-sublattice model for the properties of the liquid phase. The modified quasichemical model was chosen by Kongoli et al. ${ }^{[7]}$ and Degterov and Pelton ${ }^{[8]}$ to model the liquid solution with two different Gibbs energies for the copper-rich phase and a sulfur-rich molten phase. The extended modified quasichemical model was applied to the molten copper-sulfur solution phase for the first time by Waldner and Pelton. ${ }^{[9]}$ Lee et al. ${ }^{[10]}$ performed Gibbs energy modeling for various $\mathrm{Cu}-\mathrm{S}$ solid phases where an associate solution model specifically for the liquid phase was considered to compute the phase diagram of the $\mathrm{Cu}-\mathrm{S}$ system. Within a critical assessment and thermodynamic modeling of the $\mathrm{Cu}-\mathrm{O}$ and $\mathrm{Cu}-\mathrm{O}-\mathrm{S}$ systems, Shishin and Decterov ${ }^{[11]}$ described the Gibbs energy of the $\mathrm{Cu}-\mathrm{S}$ liquid solution phase on the basis of the optimization by Waldner and Pelton. ${ }^{[9]}$ Jantzen et al. ${ }^{[12]}$ took copper sulfide $\mathrm{Cu}_{2} \mathrm{~S}$ as the liquid solution constituent into account for their calculation of the $\mathrm{Cu}-\mathrm{S}$ phase diagram.

The purpose of this study is a comprehensive thermodynamic description of the copper-sulfur liquid solution over the whole composition range considering all experimental data available in the literature. Based on recent studies on the solid system phases by Waldner, ${ }^{[13,14]}$ the obtained model should provide the final contribution for the completion of the thermodynamic modeling of all known copper-sulfur phases to present the complete $T-x$ phase diagram from room to liquidus temperatures. In view of successful application of the extended modified quasichemical model to $\mathrm{Fe}-\mathrm{S},{ }^{[15]} \mathrm{Ni}-\mathrm{S},{ }^{[16]} \mathrm{Cr}-\mathrm{S}^{[17]}$ and subsequently to the 
ternaries Fe-Ni-S ${ }^{[18]}$ and Fe-Cr-S ${ }^{[19]}$ the same model is selected and tested for the $\mathrm{Cu}-\mathrm{S}$ liquid phase to guarantee internal consistency within a larger thermodynamic database for metal-sulfur systems. Additionally the calculation of another type phase diagram, that is a $\log p_{\mathrm{S} 2}-1 / T$ diagram, will be presented for the first time offering an alternative survey over the complete $\mathrm{Cu}-\mathrm{S}$ system.

\section{EXPERIMENTAL DATA FROM THE LITERATURE}

A chronological order determines the sequence of the following quotations of experimental data from the literature within the subsequent sections for experimental data on thermodynamic properties and phase equilibria of the $\mathrm{Cu}-\mathrm{S}$ liquid phase. Although related only to $\mathrm{Cu}-\mathrm{S}$ solid phases, the publications from Sudo, ${ }^{[20]}$ Brooks, ${ }^{[21]}$ Sadakane et al. ${ }^{[2]}$ and Brunetti et al. ${ }^{[23]}$ are considered in the section for experimental data on thermodynamic properties because they have not been treated yet in the preceding publications of Waldner ${ }^{[13,14]}$ but are relevant in this study for a comprehensive comparison with modeling results. The studies of Wehefritz, ${ }^{[24]}$ Luquet et al., ${ }^{[25]}$ Peronne et al., ${ }^{[26]}$ Dumon et al., ${ }^{[27]}$ Nagamori, ${ }^{[28]}$ Peronne and Balesdent ${ }^{[29]}$ and Sick and Schwerdtfeger have the same relevance ${ }^{[30]}$; selected data points from these will appear in the subsequent figures. However, since these seven publications were already described in detail in the corresponding sections of the preceding publications of Waldner, ${ }^{[13,14]}$ their treatment will not be repeated here.

\section{A. Thermodynamic Data}

Preuner and Brockmöller ${ }^{[31]}$ used a spiral manometer of vitreous silica for the measurement of vapor pressures of selenium, sulfur, arsenic and phosphorus to study their dissociation behavior. The equilibrium vapor pressure of sulfur related to phase equilibria of the copper sulfides digenite and covellite with liquid sulfur was also determined. Based on the known vapor pressure of pure liquid sulfur, Allen and Lombard ${ }^{[32]}$ measured the dissociation pressure of covellite and pyrite. The sulfides and liquid sulfur were placed in separate chambers at the ends of an evacuated glass. While the temperature of pure sulfur and consequently its vapor pressure were varied, the sulfides were kept at the temperature at which the dissociation pressure was to be measured. Cox et al. ${ }^{[33]}$ carried out measurements of equilibria between sulfides of copper, manganese and iron with hydrogen. Using $\mathrm{H}_{2} \mathrm{~S} / \mathrm{H}_{2}$ gas mixtures, sulfur potentials over copper sulfides according to $\mathrm{Cu}_{2} \mathrm{~S}$ composition are reported for the temperature range between $972 \mathrm{~K}$ and $1519 \mathrm{~K}\left(700{ }^{\circ} \mathrm{C}\right.$ and $\left.1246{ }^{\circ} \mathrm{C}\right)$. Sudo ${ }^{[34,35]}$ investigated the reduction of copper sulfide in molten copper by hydrogen gas in the temperature range of $1388 \mathrm{~K}\left(1115^{\circ} \mathrm{C}\right)$ up to $1518 \mathrm{~K}\left(1245^{\circ} \mathrm{C}\right)$. Reactions of $\mathrm{H}_{2} \mathrm{~S} / \mathrm{H}_{2}$ gas mixtures with melts along the composition range of the two-liquid region to cuprous sulfide $\left(\mathrm{Cu}_{2} \mathrm{~S}\right)$ were performed. The same experimental technique was applied by Sudo ${ }^{[20]}$ for studying the reduction of solid cuprous sulfide in the temperature range between $1000 \mathrm{~K}$ and $1145 \mathrm{~K}\left(727^{\circ} \mathrm{C}\right.$ and $\left.872{ }^{\circ} \mathrm{C}\right)$. Schuhmann and Moles ${ }^{[36]}$ performed an equilibrium study at temperatures of $1423 \mathrm{~K}, 1523 \mathrm{~K}$ and $1623 \mathrm{~K}$ $\left(1150{ }^{\circ} \mathrm{C}, 1250{ }^{\circ} \mathrm{C}\right.$ and $1350{ }^{\circ} \mathrm{C}$ ) for liquid copper sulfides ranging in composition from saturation with $\mathrm{Cu}$ to about $21.5 \mathrm{wt}$ pet $\mathrm{S}$. The activity of dissolved sulfur $\mathrm{S}$ has been investigated according to the reaction $\underline{\mathrm{S}}(\mathrm{l})+\mathrm{H}_{2}(\mathrm{~g}) \rightarrow \mathrm{H}_{2} \mathrm{~S}(\mathrm{~g})$. Hirakoso et al. ${ }^{[37]}$ have performed an experimental study on the reaction of hydrogen with sulfur in molten copper at temperatures from $1418 \mathrm{~K}$ to $1520 \mathrm{~K}\left(1145^{\circ} \mathrm{C}\right.$ to $\left.1247{ }^{\circ} \mathrm{C}\right)$. Between $615 \mathrm{~K}$ and $1310 \mathrm{~K}\left(342{ }^{\circ} \mathrm{C}\right.$ and $\left.1037^{\circ} \mathrm{C}\right)$ Brooks ${ }^{[21]}$ has carried out a thermodynamic study of the equilibrium 2 $\mathrm{Cu}(\mathrm{s})+\mathrm{H}_{2} \mathrm{~S}(\mathrm{~g})=\mathrm{Cu}_{2} \mathrm{~S}(\mathrm{~s})+\mathrm{H}_{2}(\mathrm{~g})$ by a recirculating technique for avoiding effects of thermal diffusion. Yagihashi ${ }^{[38]}$ has measured the equilibrium between $\mathrm{H}_{2} \mathrm{~S} / \mathrm{H}_{2}$ gas mixtures and sulfur in liquid copper for the temperature range of $1373 \mathrm{~K}$ to $1473 \mathrm{~K}\left(1100{ }^{\circ} \mathrm{C}\right.$ to $1200{ }^{\circ} \mathrm{C}$ ) and sulfur content up to $0.92 \mathrm{wt}$ pct. The temperature range from $800 \mathrm{~K}$ to $1425 \mathrm{~K}\left(527^{\circ} \mathrm{C}\right.$ to $1152{ }^{\circ} \mathrm{C}$ ) was chosen by Richardson and Antill ${ }^{[39]}$ to bring cuprous sulfide and its mixtures with sodium sulfide into equilibrium with free copper and a gas mixture consisting of hydrogen and hydrogen sulfide. A radiochemical method based on the sulfur isotope $S^{35}$ has been used by Alcock ${ }^{[40]}$ for studying high-temperature equilibria involving $\mathrm{H}_{2} \mathrm{~S} / \mathrm{H}_{2}$ gas mixtures. Dickson et al. $^{[41]}$ applied the dew point technique for measuring the sulfur pressure for the Reaction $2 \mathrm{CuS}(\mathrm{s})=\mathrm{Cu}_{2} \mathrm{~S}(\mathrm{~s})$ $+\mathrm{S}(\mathrm{g})$ using artificial covellite as starting material. Using the dew point method as direct and gas equilibration with $\mathrm{H}_{2} \mathrm{~S} / \mathrm{H}_{2}$ mixtures as indirect method, $\mathrm{Rau}^{[42]}$ determined sulfur fugacities of digenite between $789 \mathrm{~K}$ and $1321 \mathrm{~K}\left(516{ }^{\circ} \mathrm{C}\right.$ and $\left.1048{ }^{\circ} \mathrm{C}\right)$. Nagamori and Rosenqvist $^{[43]}$ equilibrated $\mathrm{Cu}-\mathrm{S}$ melts around 34 at. pet $\mathrm{S}$ under $\mathrm{S}_{2} / \mathrm{N}_{2}$ gas mixtures for determination of the partial pressure of sulfur and the sulfur activity-composition relation at $1473 \mathrm{~K}\left(1200{ }^{\circ} \mathrm{C}\right)$. Bale and Toguri ${ }^{[44]}$ applied a thermogravimetric technique for continuous quantitative sulfur analysis of copper-sulfur samples equilibrated with $\mathrm{H}_{2} \mathrm{~S} / \mathrm{H}_{2}$ gas mixtures at $1473 \mathrm{~K}$ $\left(1200{ }^{\circ} \mathrm{C}\right)$. Vanyukov et al. ${ }^{[45]}$ applied the dew point method for measurements of sulfur vapor pressure on liquid and solid sulfide samples in the temperature range from about $823 \mathrm{~K}$ to $1523 \mathrm{~K}\left(550{ }^{\circ} \mathrm{C}\right.$ to $\left.1250{ }^{\circ} \mathrm{C}\right)$. On the basis of the first study of Rau, ${ }^{[42]}$ investigations were extended to the whole homogeneity range from the copper-rich to the sulfur-rich boundary of digenite by Rau. ${ }^{[46]}$ Using oxygen concentration cells with $\mathrm{ZrO}_{2}$. $\mathrm{CaO}$ as electrolyte material, Sadakane et al. ${ }^{[22]}$ carried out electromotive force (emf) measurements in the temperature range from $963 \mathrm{~K}$ to $1286 \mathrm{~K}\left(690^{\circ} \mathrm{C}\right.$ to $\left.1013{ }^{\circ} \mathrm{C}\right)$. Sulfur potential data related to digenite/ $\mathrm{Cu}$-alloy phase equilibria are reported. Bale and Toguri $^{[47]}$ used the same method as in their former study of Bale and Toguri ${ }^{[44]}$ for two additional temperatures at $1423 \mathrm{~K}$ and $1523 \mathrm{~K}\left(1150{ }^{\circ} \mathrm{C}\right.$ and $\left.1250{ }^{\circ} \mathrm{C}\right)$ reporting sulfur partial pressures together with liquid phase equilibria data on the $\mathrm{Cu}-\mathrm{S}, \mathrm{Fe}-\mathrm{S}$ and $\mathrm{Cu}-\mathrm{Fe}-\mathrm{S}$ systems. Judin and Eerola ${ }^{[48]}$ applied the equilibration 
method with $\mathrm{H}_{2} \mathrm{~S} / \mathrm{H}_{2}$ gas mixtures between $1423 \mathrm{~K}$ and $1573 \mathrm{~K}\left(1150{ }^{\circ} \mathrm{C}\right.$ and $\left.1300{ }^{\circ} \mathrm{C}\right)$ employing studies of the miscibility gap in the binary $\mathrm{Cu}-\mathrm{Cu}_{2} \mathrm{~S}$ and the ternary $\mathrm{Cu}-\mathrm{Bi}-\mathrm{S}$ system. Koh and Yazawa ${ }^{[49]}$ determined sulfur potentials of the $\mathrm{Cu}-\mathrm{S}, \mathrm{Fe}-\mathrm{S}$ and $\mathrm{Cu}-\mathrm{Fe}-\mathrm{S}$ systems at $1523 \mathrm{~K}\left(1250^{\circ} \mathrm{C}\right)$ by equilibration of the liquid matte (metallurgical notation for sulfur-rich liquid phase in opposite to the metallic melt) with gaseous mixtures of $\mathrm{H}_{2}$ and $\mathrm{H}_{2} \mathrm{~S}$. Tie lines along the miscibility gap between matte and metal phase were also studied. Niemelä and Taskinen $^{[50]}$ studied sulfur activities and phase equilibria of molten $\mathrm{Cu}-\mathrm{S}$ samples from pure copper to cuprous sulfide. An emf technique using an oxygen concentration cell was used in the temperature range from $1423 \mathrm{~K}$ up to $1623 \mathrm{~K}\left(1150{ }^{\circ} \mathrm{C}\right.$ up to $\left.1350{ }^{\circ} \mathrm{C}\right)$. Westrum et al. ${ }^{[51]}$ measured the sulfur vapor pressure of sulfur by the dew point method between $753 \mathrm{~K}$ and $843 \mathrm{~K}\left(480{ }^{\circ} \mathrm{C}\right.$ and $570{ }^{\circ} \mathrm{C}$ ) sealing covellite in an evacuated silica-glass tube. The torsion-effusion method was applied by Brunetti et al. ${ }^{[23]}$ for determination of the sulfur vapor pressure related to covellite $(\mathrm{CuS})$ between $551 \mathrm{~K}$ and $627 \mathrm{~K}\left(278{ }^{\circ} \mathrm{C}\right.$ and $\left.354{ }^{\circ} \mathrm{C}\right)$.

The enthalpy of fusion of $\mathrm{Cu}_{2} \mathrm{~S}$ as another type of thermodynamic data was also subject of experimental studies. Friedrich ${ }^{[52]}$ derived this quantity from freezing point depressions in the systems $\mathrm{Cu}_{2} \mathrm{~S}-\mathrm{Ni}_{3} \mathrm{~S}_{2}$ and $\mathrm{Cu}_{2} \mathrm{~S}-\mathrm{Ni}_{2} \mathrm{~S}$. According to Johannsen and Vollmer ${ }^{[53]}$ the first direct measurement of the enthalpy of fusion of $\mathrm{Cu}_{2} \mathrm{~S}$ was reported using water calorimetry. Mendelevich et al. ${ }^{[54]}$ performed differential thermal analysis, whereas Ferrante et al. ${ }^{[55]}$ applied a copper-block calorimetry to determine the enthalpy of fusion of $\mathrm{Cu}_{2} \mathrm{~S}$.

\section{B. Phase Diagram Data}

Heyn and Bauer ${ }^{[56]}$ investigated the liquidus and solidus of the copper-sulfur system analyzing freezing-point curves and the microstructure of mixtures within the composition range of 9 to 85 wt pct $\mathrm{Cu}_{2} \mathrm{~S}$. Friedrich and Waehlert ${ }^{[57]}$ studied the region of demixing in the metal-rich part of the copper-sulfur system carrying out thermal analysis from $1423 \mathrm{~K}$ up to $1758 \mathrm{~K}$ $\left(1150^{\circ} \mathrm{C}\right.$ up to $\left.1485^{\circ} \mathrm{C}\right)$. Bornemann and Wagenmann ${ }^{[58]}$ determined the miscibility gap of the $\mathrm{Cu}-\mathrm{Cu}_{2} \mathrm{~S}$ system up to $1350{ }^{\circ} \mathrm{C}$ using electrical conductivity measurements. Smith ${ }^{[59]}$ studied alloys of copper with small amounts of sulfur, selenium and tellurium carrying out constitutional and microstructural analysis. Differential thermal analysis was applied by Jensen ${ }^{[60]}$ to elucidate the melting relations of copper-sulfur samples between 77 and 82 wt pct copper. No solid-state transformation is reported between $677 \mathrm{~K}\left(404{ }^{\circ} \mathrm{C}\right)$ and melting temperatures. Johannsen and Vollmer ${ }^{[53]}$ carried out thermal analysis for studying the $\mathrm{Cu}-\mathrm{Cu}_{2} \mathrm{~S}$ system between $1340 \mathrm{~K}$ and $1523 \mathrm{~K}\left(1067{ }^{\circ} \mathrm{C}\right.$ and $\left.1250{ }^{\circ} \mathrm{C}\right)$ up to $22 \mathrm{wt}$ pet sulfur. A partial phase diagram around the digenite phase field was presented by Roseboom ${ }^{[61]}$ applying an evacuated diffractometer heating stage. Synthetic and natural phases were studied in the temperature range from $298 \mathrm{~K}$ and $973 \mathrm{~K}\left(25^{\circ} \mathrm{C}\right.$ to $700{ }^{\circ} \mathrm{C}$ ). A remarkably large body of precise phase boundary data around the digenite field were reported by Cook $^{[62]}$ who performed differential thermal analysis (DTA), powder X-ray diffraction and a technique observing the growth of copper whiskers. Schmiedl et al. $^{[63]}$ investigated the equilibria within the miscibility gap between two liquid phases at temperatures of 1423 $\mathrm{K}, 1473 \mathrm{~K}$ and $1523 \mathrm{~K}\left(1150{ }^{\circ} \mathrm{C}, 1200^{\circ} \mathrm{C}\right.$ and $\left.1250{ }^{\circ} \mathrm{C}\right)$ using a combustion method. Copper-rich samples were burned in a stream of oxygen whereas those of the matte phase in a stream of air. The same region of the $\mathrm{Cu}-\mathrm{S}$ system was studied by Moulkl and Osterwald ${ }^{[64]}$ who presented equilibria data up to $1773 \mathrm{~K}\left(1500{ }^{\circ} \mathrm{C}\right)$ estimating the critical point of the miscibility gap close to $1783 \mathrm{~K}\left(1510^{\circ} \mathrm{C}\right)$. Chemical analysis of the samples was performed gravimetrically. Glazov et al. ${ }^{[65]}$ applied a high-temperature method of measuring the acoustic properties of copper-sulfur melts in the metallic rich region of the liquid-liquid phase separation. The critical point is given at $1858 \mathrm{~K}\left(1585^{\circ} \mathrm{C}\right)$ at a sulfur content of 17.5 at. pct.

A valuable stock of phase equilibria data also exists, which were not determined directly but derived from thermodynamic data published by Sudo, ${ }^{[35]}$ Schuhmann and Moles, ${ }^{[36]}$ Rau, ${ }^{[42,46]}$ Bale and Toguri, ${ }^{[47]}$ Judin and Eerola, ${ }^{[48]}$ Koh and Yazawa, ${ }^{[49]}$ and Niemelä and Taskinen. ${ }^{[50]}$ These publications were already treated in the preceding section, and data derived from their phase diagrams are considered in this study as well.

\section{THERMODYNAMIC MODELING OF THE LIQUID PHASE}

Thermodynamic modeling in this study is about CALPHAD-type modeling for the Gibbs energy of the copper-sulfur liquid phase with its dependency on temperature and composition. Due to the lack of experimental data for pressure dependency, this work is focused on a total pressure of one bar. Adjustable parameters of the applied Gibbs energy expression are calculated via an 'optimization' process using critically evaluated experimental thermodynamic and phase equilibria data simultaneously. The obtained model parameters allow a self-consistent application of the model equation to re-calculate all the experimental data. Furthermore, analysis of discrepancies in the available experimental data, interpolative and extrapolative predictions in experimentally not investigated or even inaccessible regions are accompanied with thermodynamic principles.

The copper-sulfur liquid solution exhibits two thermodynamic peculiarities such that not only a miscibility gap on the sulfur-rich side of the $T-x$ phase diagram exists but also in the metal-rich regimes between a metallic copper and a sulfide melt around $1 / 3$ mole fraction of sulfur. Furthermore, due to short range ordering, the sulfur potential changes by several orders of magnitude over a narrow composition range close to $1 / 3$ mole fraction of sulfur instead to 50 at. pct sulfur with a symmetric position on the composition axis of other binary metal sulfur systems $\mathrm{M}-\mathrm{S}$ with, e.g., $\mathrm{M}=$ $\mathrm{Fe}, \mathrm{Ni}$, Co or $\mathrm{Cr}$. To consider short range ordering at compositions around $1 / 3$ mole fraction of sulfur, an 
improved version of the modified quasi-chemical model of Pelton and Blander ${ }^{[66]}$ is applied for the analytical description of the Gibbs energy of the liquid phase. The new version from Pelton et al. ${ }^{[67]}$ has been applied successfully for the first time to binary liquid solutions of the Fe-S, ${ }^{[15]} \mathrm{Ni}-\mathrm{S}^{[16]}$ and $\mathrm{Cr}-\mathrm{S}^{[17]}$ systems as well as to ternary Fe-Ni-S ${ }^{[18]}$ and Fe-Cr-S ${ }^{[19]}$ melts. This extended modified quasi-chemical model ${ }^{[67]}$ considers a pair exchange reaction between $\mathrm{Cu}$ and $\mathrm{S}$ atoms distributed over the sites of a quasi-lattice as follows:

$$
(\mathrm{Cu}-\mathrm{Cu})+(\mathrm{S}-\mathrm{S})=2(\mathrm{Cu}-\mathrm{S})
$$

The $(\mathrm{Cu}-\mathrm{S})$ pairs are first-nearest-neighbors. The non-configurational Gibbs energy change for the formation of two moles of $(\mathrm{Cu}-\mathrm{S})$ pairs according to the reaction of Eq. [1] is $\Delta g_{\mathrm{CuS}}$, which occurs in the excess term of the total Gibbs energy:

$$
G=\left(n_{\mathrm{Cu}} g_{\mathrm{Cu}}^{\mathrm{o}}+n_{\mathrm{S}} g_{\mathrm{S}}^{\mathrm{o}}\right)-T \Delta S^{\mathrm{config}}+\left(n_{\mathrm{CuS}} / 2\right) \Delta g_{\mathrm{CuS}}
$$

The quantities $g_{\mathrm{Cu}}^{\mathrm{o}}$ and $g_{\mathrm{S}}^{\mathrm{o}}$ represent the molar Gibbs energies of the pure components, $n_{\mathrm{Cu}}$ and $n_{\mathrm{S}}$ are the numbers of moles of copper and sulfur atoms, and $n_{\mathrm{CuS}}$ is the number of moles of copper-sulfur pairs. The second term contains $\Delta S_{\text {config }}$ as the configurational entropy of mixing given by a random distribution of the $(\mathrm{Cu}-\mathrm{Cu}),(\mathrm{S}-\mathrm{S})$ and $(\mathrm{Cu}-\mathrm{S})$ pairs in the one-dimensional Ising approximation ${ }^{[67]}$ :

$$
\begin{aligned}
\Delta S^{\text {config }}= & -R\left(n_{\mathrm{Cu}} \ln X_{\mathrm{Cu}}+n_{S} \ln X_{S}\right) \\
& -R\left[n_{C u C u} \ln \left(X_{C u C u} / Y_{\mathrm{Cu}}^{2}\right)+n_{S S} \ln \left(X_{S S} / Y_{S}^{2}\right)\right. \\
& \left.+n_{\mathrm{CuS}} \ln \left(X_{\mathrm{CuS}} / 2 Y_{\mathrm{Cu}} Y_{S}\right)\right]
\end{aligned}
$$

The mole fractions $X_{\mathrm{i}}$ and coordination equivalent fractions $Y_{\mathrm{i}}$ with the coordination numbers $Z_{\mathrm{i}}$ are defined as $X_{\mathrm{i}}=n_{\mathrm{i}} /\left(n_{\mathrm{i}}+n_{\mathrm{S}}\right)$ and $Y_{\mathrm{i}}=Z_{\mathrm{i}} n_{\mathrm{i}} /\left(Z_{\mathrm{Cu}} n_{\mathrm{Cu}}+\right.$ $\left.Z_{\mathrm{S}} n_{\mathrm{S}}\right)$ with $\mathrm{i}=\mathrm{Cu}$ and $\mathrm{S}$. The pair fraction $X_{\mathrm{CuCu}}$ is given by the ratio $X_{\mathrm{CuCu}}=n_{\mathrm{CuCu}} /\left(n_{\mathrm{CuCu}}+n_{\mathrm{SS}}+n_{\mathrm{CuS}}\right)$. The remaining two pair fractions $X_{\mathrm{SS}}$ and $X_{\mathrm{CuS}}$ are calculated analogously. The coordination numbers of copper and sulfur can vary with composition according to the extended modified quasi-chemical model as follows:

$$
\frac{1}{Z_{\mathrm{Cu}}}=\frac{1}{Z_{\mathrm{CuCu}}}\left(\frac{2 n_{\mathrm{CuCu}}}{2 n_{\mathrm{CuCu}}+n_{\mathrm{CuS}}}\right)+\frac{1}{Z_{\mathrm{CuS}}}\left(\frac{n_{\mathrm{CuS}}}{2 n_{\mathrm{CuCu}}+n_{\mathrm{CuS}}}\right)
$$

$$
\frac{1}{Z_{S}}=\frac{1}{Z_{\mathrm{SS}}}\left(\frac{2 n_{\mathrm{SS}}}{2 n_{\mathrm{SS}}+n_{\mathrm{CuS}}}\right)+\frac{1}{Z_{S C u}}\left(\frac{n_{\mathrm{CuS}}}{2 n_{\mathrm{SS}}+n_{\mathrm{CuS}}}\right)
$$

where $Z_{\mathrm{CuCu}}$ stands for the coordination number when all nearest neighbors of copper are exclusively copper atoms and $Z_{\mathrm{CuS}}$ is the value when all nearest neighbors are sulfur atoms. The quantities $Z_{\mathrm{SS}}$ and $Z_{\mathrm{SCu}}$ are defined in the same way with sulfur being the central atom within its neighborhood. The ratio $\left(Z_{\mathrm{CuS}} / Z_{\mathrm{SCu}}\right)$ determines the composition of maximum short range ordering.
Finally, the third term of Eq. [2] as the excess Gibb energy contains a model quantity $\Delta g_{\mathrm{CuS}}$, which is the non-configurational Gibbs energy change for the formation of two moles of $(\mathrm{Cu}-\mathrm{S})$ pairs according to reaction [1]. The balance of the dominating side of reaction [1] is controlled by this quantity. If $\Delta g_{\mathrm{CuS}}$ is substantially negative, then $(\mathrm{Cu}-\mathrm{S})$ pairs dominate at the expense of $(\mathrm{Cu}-\mathrm{Cu})$ and $(\mathrm{S}-\mathrm{S})$ pairs. The composition dependence of $\Delta g_{\mathrm{CuS}}$ is expressed via a polynomial expansion in terms of the pair fractions:

$$
\Delta g_{\mathrm{CuS}}=\Delta g_{\mathrm{CuS}}^{\mathrm{o}}+\sum_{i \geq 1} g_{\mathrm{CuS}}^{\mathrm{io}} X_{\mathrm{CuCu}}^{\mathrm{i}}+\sum_{j \geq 1} g_{\mathrm{CuS}}^{\mathrm{oj}} X_{\mathrm{SS}}^{\mathrm{j}}
$$

Equation [6] offers adjustable parameters $\Delta g_{\mathrm{CuS}}^{\mathrm{o}}, g_{\mathrm{CuS}}^{\text {io }}$ and $g_{\mathrm{Cus}}^{\mathrm{oj}}$, which can be modeled as temperature dependent in case of necessity. The superscript $i$ together with a ring on the right side identifies the parameters $g_{\mathrm{Cus}}^{\text {io }}$. Within the first summation term of Eq. [6], this parameter is weighted by the pair fraction $X_{\mathrm{CuCu}}$ being exponentiated by $i$. The parameter $g_{\text {Cus }}^{\text {io }}$ may be selected and optimized in copper-rich regimes where $\mathrm{Cu}-\mathrm{Cu}$ pairs at the cost of $(\mathrm{Cu}-\mathrm{S})$ and $(\mathrm{S}-\mathrm{S})$ pairs dominate and consequently may have a relevant effect on the Gibbs energy. The superscripts $\mathrm{j}$ together with a ring on the left side play an analogous role as an identifier for the parameter $g_{\mathrm{CuS}}^{\text {oj }}$ and as an exponent for the pair fraction $X_{\mathrm{SS}}$.

\section{RESULTS}

The optimization process for modeling the Gibbs energy of the liquid phase resulted in the selection and computation of six excess Gibbs energy parameters. Table I lists all the computed values using the equivalent notation of the corresponding quantities of Eq. [6]. It turned out that best optimization results can be achieved by adjusting two parameters, $g_{\text {Cus }}^{\text {io }}$ with $i=1$ and 2 , for the copper-rich regimes and three parameters $g_{\mathrm{Cu}}^{\mathrm{oj}}$ with $\mathrm{j}$ $=1,2$ and 4 for sulfur-rich regimes of the liquid solution phase. The need for temperature dependency arises only for two parameters. At least two digits are given after the decimal point for the noted excess enthalpies and entropies. Consequently, the reader should be able to reproduce all the data presented in the figures and tables of this work.

Standard Gibbs energy functions $g_{\mathrm{i}}^{0}$ for pure liquid copper and sulfur were taken from the SGTE (Scientific Group Thermodata Europe) unary database for pure elements, compiled by Dinsdale. ${ }^{[68]}$ Standard Gibbs energy functions of gaseous species are taken from the SGTE pure substance database. Using the thermodynamically ideal description of the gas phase, gaseous species of sulfur such as $\mathrm{S}_{\mathrm{n}}(\mathrm{g})$ from $\mathrm{S}_{1}(\mathrm{~g})$ to $\mathrm{S}_{8}(\mathrm{~g})$ as well as of $\mathrm{Cu}(\mathrm{g}), \mathrm{Cu}_{2}(\mathrm{~g}), \mathrm{CuS}(\mathrm{g})$ and $\mathrm{Cu}_{2} \mathrm{~S}(\mathrm{~g})$ are taken into consideration.

One of the specialties of the copper-sulfur system, as opposed to other metal-sulfur systems, such as Fe-S, ${ }^{[15]}$ $\mathrm{Ni}-\mathrm{S}^{[16]}$ or $\mathrm{Cr}-\mathrm{S},{ }^{[17]}$ is the asymmetric composition of maximum short-range ordering in the liquid phase at a mole fraction ratio $\left(x_{\mathrm{S}} / x_{\mathrm{Cu}}\right)$ of $1 / 2$. Consequently, the 
Table I. Optimized Excess Gibbs Energy Parameters of the Liquid Phase in $\mathrm{J} \mathrm{mol}^{-1}$

\begin{tabular}{ll}
\hline$\Delta g_{\mathrm{CuS}}^{0}$ & $=-62,467.12-11.071 T$ \\
$g_{\mathrm{CuS}}^{10}$ & $=+45,905.22$ \\
$g_{\mathrm{CuS}}^{20}$ & $=-14,509.55$ \\
$\mathrm{~g}_{\mathrm{CuS}}^{01}$ & $=+9,652.05$ \\
$g_{\mathrm{CuS}}^{02}$ & $=+33,890.40-15.188 T$ \\
$g_{\mathrm{CuS}}^{04}$ & $=+33,205.00$ \\
\hline
\end{tabular}

ratio $\left(Z_{\mathrm{CuS}} / Z_{\mathrm{SCu}}\right)$ also has to be determined with a value of $1 / 2$, which is best optimized by the binary coordination numbers $Z_{\mathrm{CuS}}$ and $Z_{\mathrm{SCu}}$, equal to 1.5 and 3.0, respectively. A value of six for the unary coordination numbers $Z_{\mathrm{SS}}$ and $Z_{\mathrm{CuCu}}$ was analyzed to give the best optimization results in line with the corresponding coordination numbers for the Fe-S, ${ }^{[15]} \mathrm{Ni}-\mathrm{S},{ }^{[16]}$ and $\mathrm{Cr}-\mathrm{S}^{[17]}$ liquid solution models.

All calculations in the framework of this study were performed using the FactSage thermodynamic software package. ${ }^{[69]}$

\section{A. Comparison of Calculation and Experimental Data}

To test the descriptive capability of the applied Gibbs energy model for the $\mathrm{Cu}-\mathrm{S}$ melt, one may focus at first on those experimental thermodynamic data such as sulfur potentials, which are exclusively related to the liquid phase. Due to the large number of experimental data on sulfur potentials of the liquid phase in various composition and temperature regimes, the presented comparison with calculation is split in two (Figures 1(a) and (b)). Figure 1(a) covers the copper metal-rich region, and Figure $1 \mathrm{~b}$ refers to the composition range around the $1 / 3$ mole fraction of sulfur where the sulfur potential shows a strong change over several orders of magnitude. Beside these magnifications of Figures 1(a) and (b), an overview of all data is given in Figure 1(c) also including the two-phase region inside the miscibility gap where many experimental data points have been reported. ${ }^{[40,47,49,50]}$ It can be seen that agreement between the experimental data on sulfur potentials and computations with the presented Gibbs energy model of the liquid phase (depicted as lines) is satisfactory.

For the computation of liquid-solid phase equilibria of the $\mathrm{Cu}-\mathrm{S}$ system using the Gibbs energy model of this study, the Gibbs energy functions of the involved solid solutions and stoichiometric compounds were taken from Waldner. ${ }^{[13,14]}$ Figures 2, 3 and 4 permit detailed insight in distinct regions of the $T-x$ phase diagram of the $\mathrm{Cu}-\mathrm{S}$ system for comparison between the experimental data and calculated phase boundaries and invariant lines. Figure 2 depicts experimental data points of various publications related to the miscibility gap between a copper- and a sulfur-rich liquid phase. On the sulfur-rich side, two inconsistent groups of data points can be distinguished. The calculated phase boundary tends to reproduce that group ${ }^{[35,36,48-50]}$ with a steeper rise resulting in an extended region of demixing at elevated temperatures. The other group of experimental data points ${ }^{[58,64,65]}$ shows a less steep rise. It should be noted that any attempt to improve the correspondence between the calculation and this group results in substantial deterioration of the correspondence with other experimental data. Figure 3 displaces the focus to higher sulfur contents from 0.3 to 0.4 mole fraction of sulfur covering all phase relations of the liquid phase with digenite. Digenite coexists above 1086 $\mathrm{K}\left(813{ }^{\circ} \mathrm{C}\right)$ with a sulfur-rich melt up to its congruent melting point at $1403 \mathrm{~K}\left(1130{ }^{\circ} \mathrm{C}\right)$ but below $1086 \mathrm{~K}$ $\left(813^{\circ} \mathrm{C}\right)$ with an almost pure sulfuric liquid phase (two-phase field $\mathrm{Dg}+\mathrm{S}_{\mathrm{liq}}$ ). Figure 4 presents a magnification of the $T-x$ phase diagram containing the sulfur-rich endpoints of two invariant lines at $1340 \mathrm{~K}$ and $1378 \mathrm{~K}\left(1067{ }^{\circ} \mathrm{C}\right.$ and $\left.1105^{\circ} \mathrm{C}\right)$. The line at $1340 \mathrm{~K}$ $\left(1067^{\circ} \mathrm{C}\right)$ constitutes the three-phase equilibrium fcc (copper alloy)/Liq(1)/Dg where Liq(1) stands for the metallic melt of the two liquid phases occurring in the copper-sulfur system below $1 / 3$ mole fraction of sulfur. The line at $1378 \mathrm{~K}\left(1105^{\circ} \mathrm{C}\right)$ manifests the monotectic three-phase equilibrium $\operatorname{Liq}(1) / \operatorname{Liq}(2) / \mathrm{Dg}$ where $\operatorname{Liq}(1)$ is again a copper-rich metallic melt and $\operatorname{Liq}(2)$ a sulfur-rich phase. Both endpoints describe the digenite equilibrium composition at $1340 \mathrm{~K}$ and $1378 \mathrm{~K}\left(1067{ }^{\circ} \mathrm{C}\right.$ and $1105^{\circ} \mathrm{C}$ ) demonstrating that the phase field of digenite also expands slightly to compositions with less sulfur content than $\mathrm{Cu}_{2} \mathrm{~S}$ stoichiometry. In general, the phase equilibria calculations shown in Figures 2 through 4 agree satisfactorily with a large body of experimental data. This can be achieved although the thermodynamic model of this study faces the challenging situation of describing three types of liquid phase simultaneously by a single Gibbs energy expression, which are structurally versatile, ranging from the highly metallic via sulfur-rich to almost pure sulfuric, denoted above as $\operatorname{Liq}(1), \operatorname{Liq}(2)$ and $S_{\text {liq }}$, respectively.

Table II presents a summary of all calculated temperatures and compositions of invariant phase equilibria where the liquid phase is involved. Computed results are comparable with data reported by Chakrabarti and Laughlin $^{[1]}$ and Chase et al. ${ }^{[70]}$ who reviewed and assessed experimental data shown in Figures 2 through 4.

Together with the recently published Gibbs energy of digenite, ${ }^{[13]}$ the thermodynamic model for the liquid phase of this work allows recalculating the experimentally determined and assessed temperatures and enthalpies of melting digenite. Table III shows that the modeled value is in line with higher values from the literature. This enthalpy of melting couples the thermodynamics of the dominating solid phase of the $\mathrm{Cu}-\mathrm{S}$ system with that of the liquid phase at a critical composition where its thermodynamics exhibit a substantial change of sulfur potentials over several orders of 


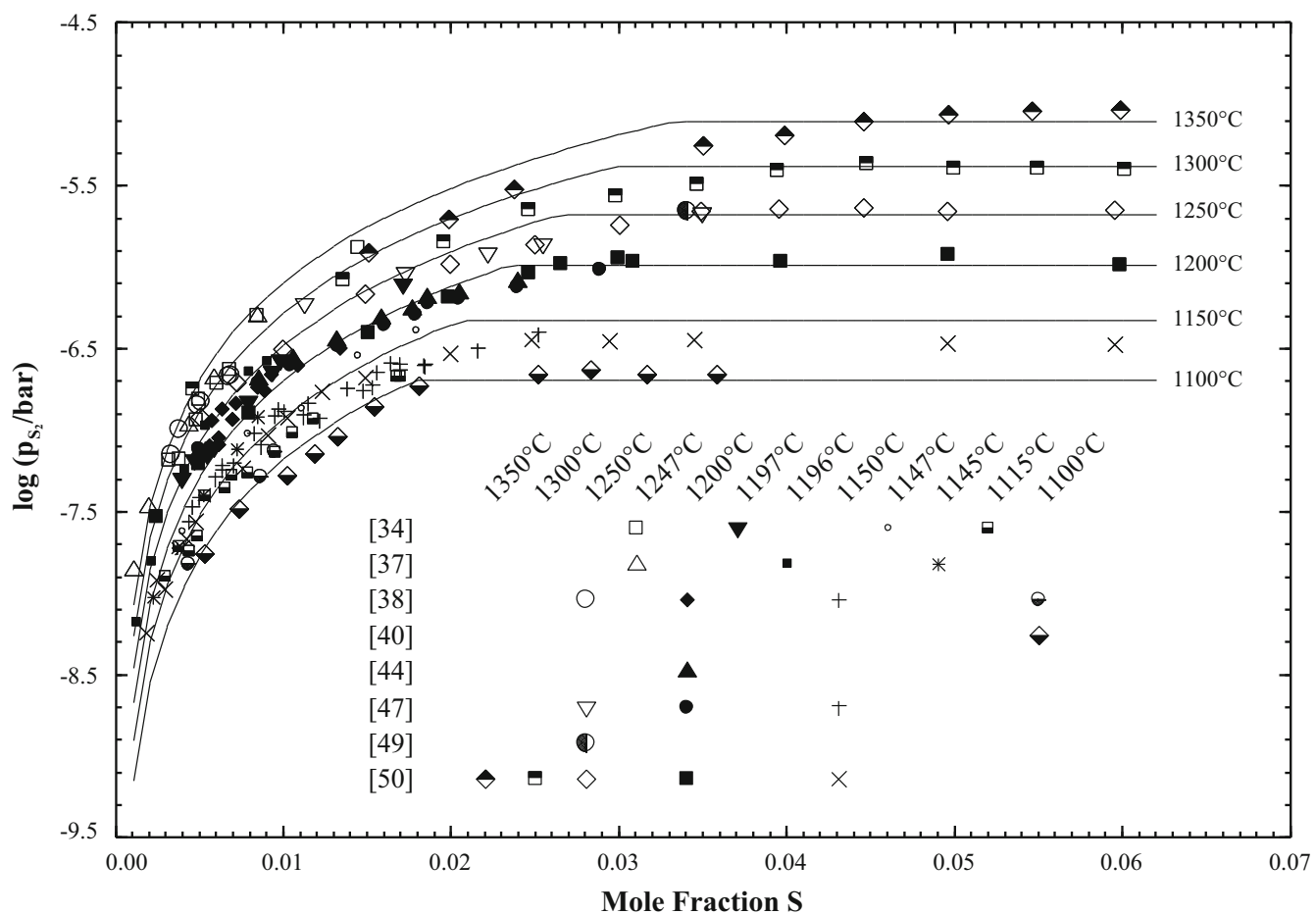

(a)

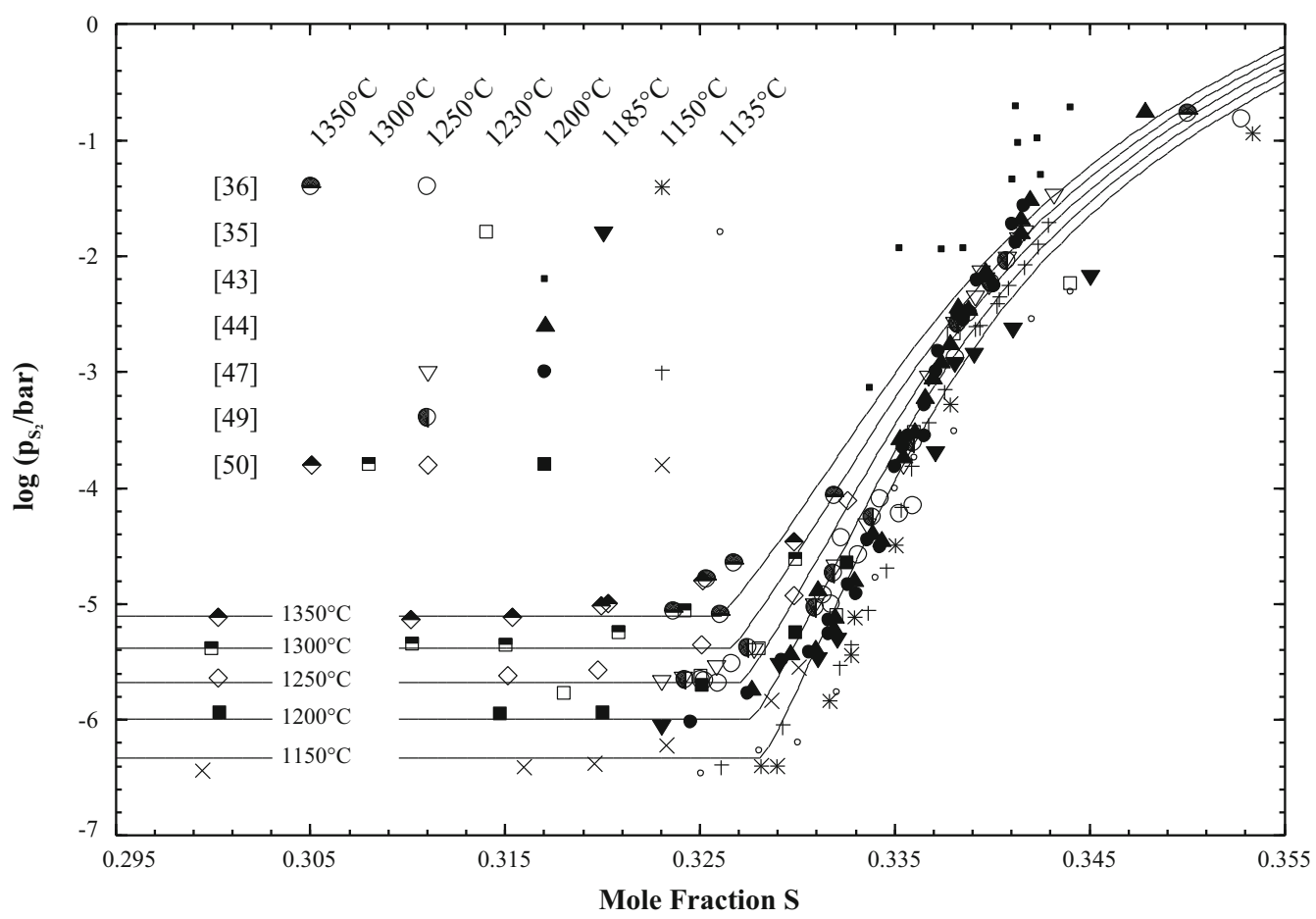

(b)

Fig. 1-(a) Calculated sulfur potential of the liquid phase and experimental data for $\mathrm{Cu}$-rich samples. (b) Calculated sulfur potential of the liquid phase and experimental data for S-rich samples. (c) Overview of the calculated sulfur potential of the liquid phase and experimental data up to 0.4 sulfur mole fraction. Calculated sulfur potentials resulted in horizontal lines within the two-phase region of the miscibility gap of the liquid phase. 


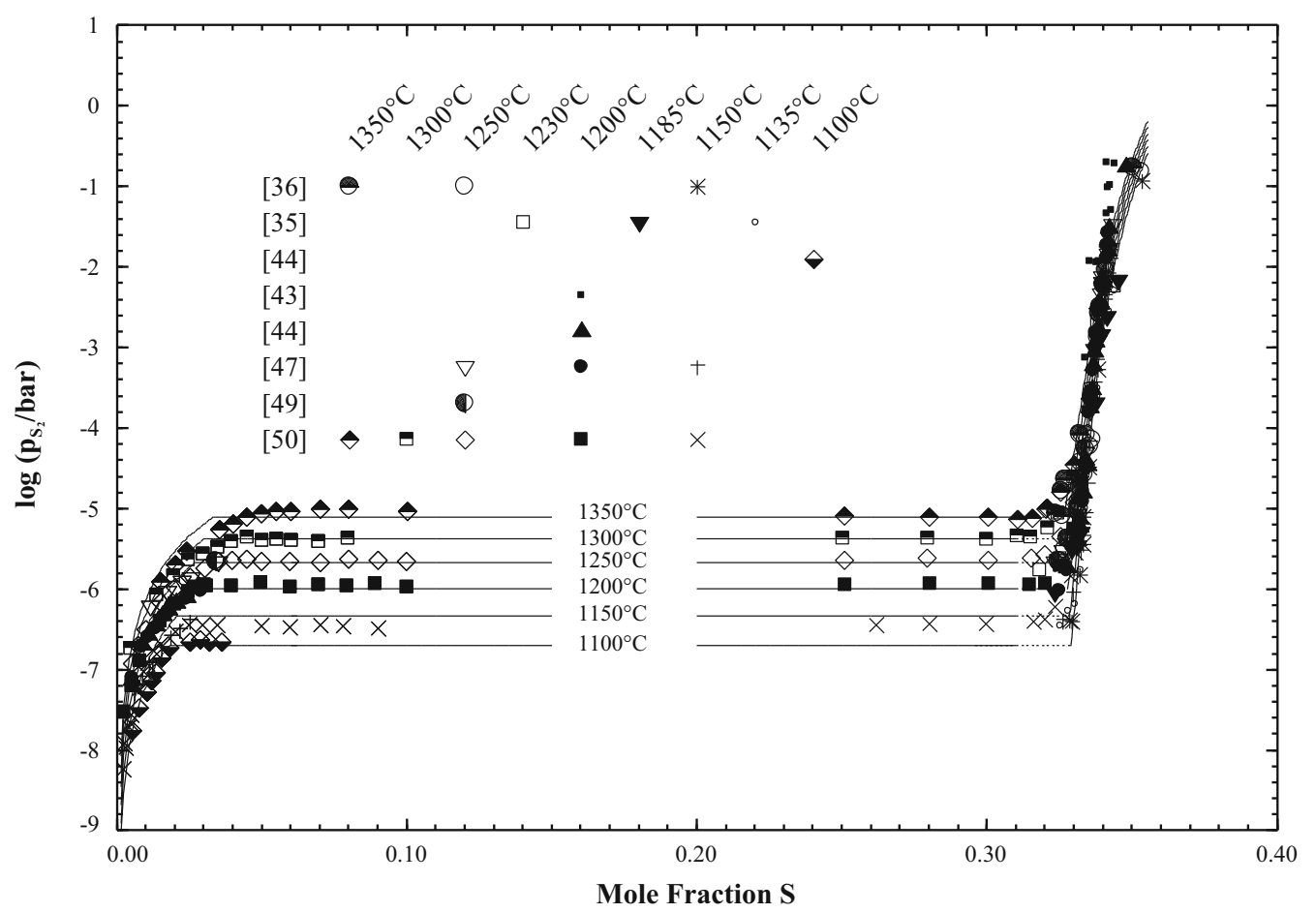

(c)

Fig. 1 - continued.

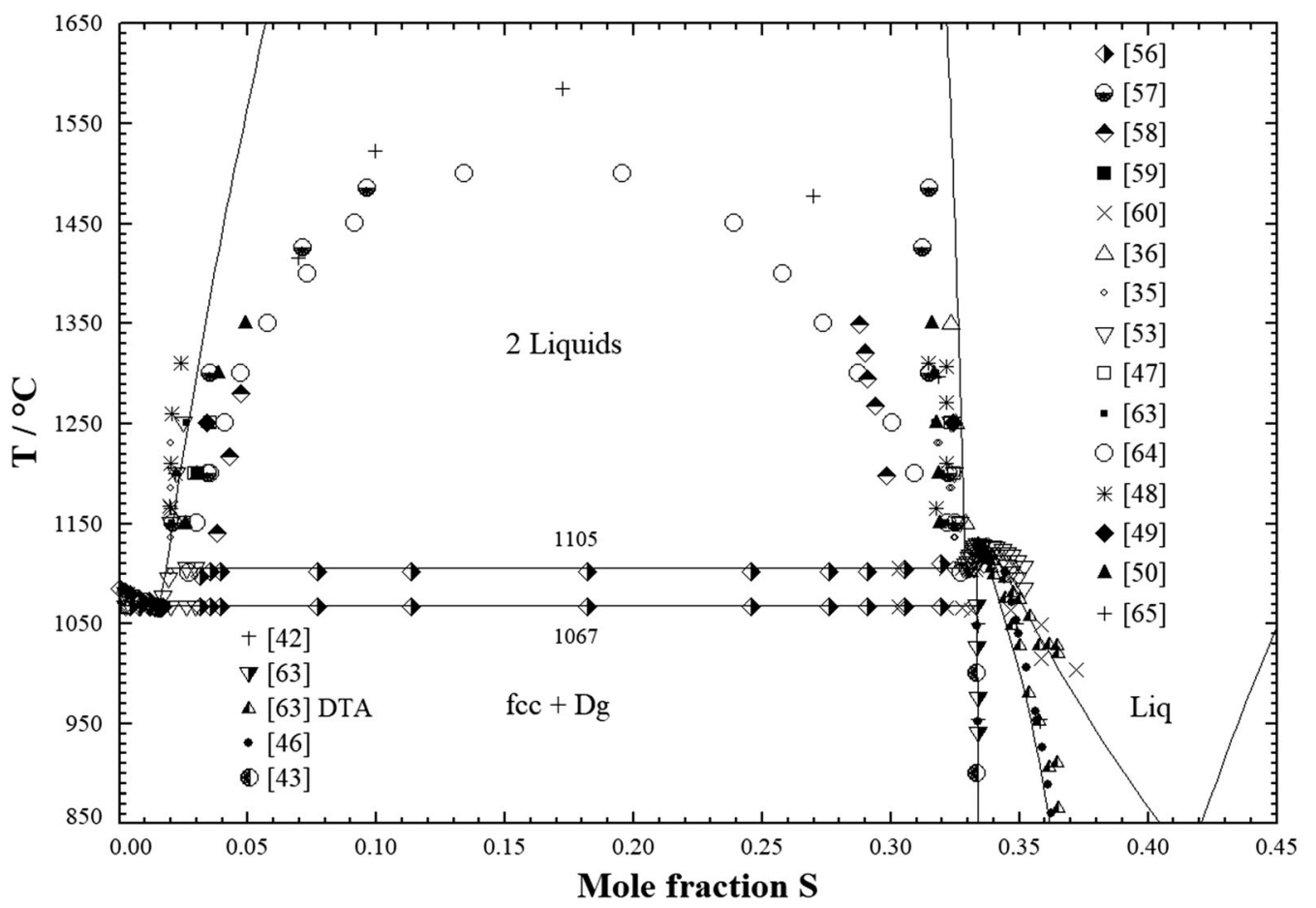

Fig. 2 - Calculated partial $T-x$ phase diagram of the binary copper-sulfur system in the composition range up to 0.45 mole fraction of sulfur at a total pressure of 1 bar together with the experimental data. Dg $=$ digenite; fcc $=$ face-centered cubic copper phase. 


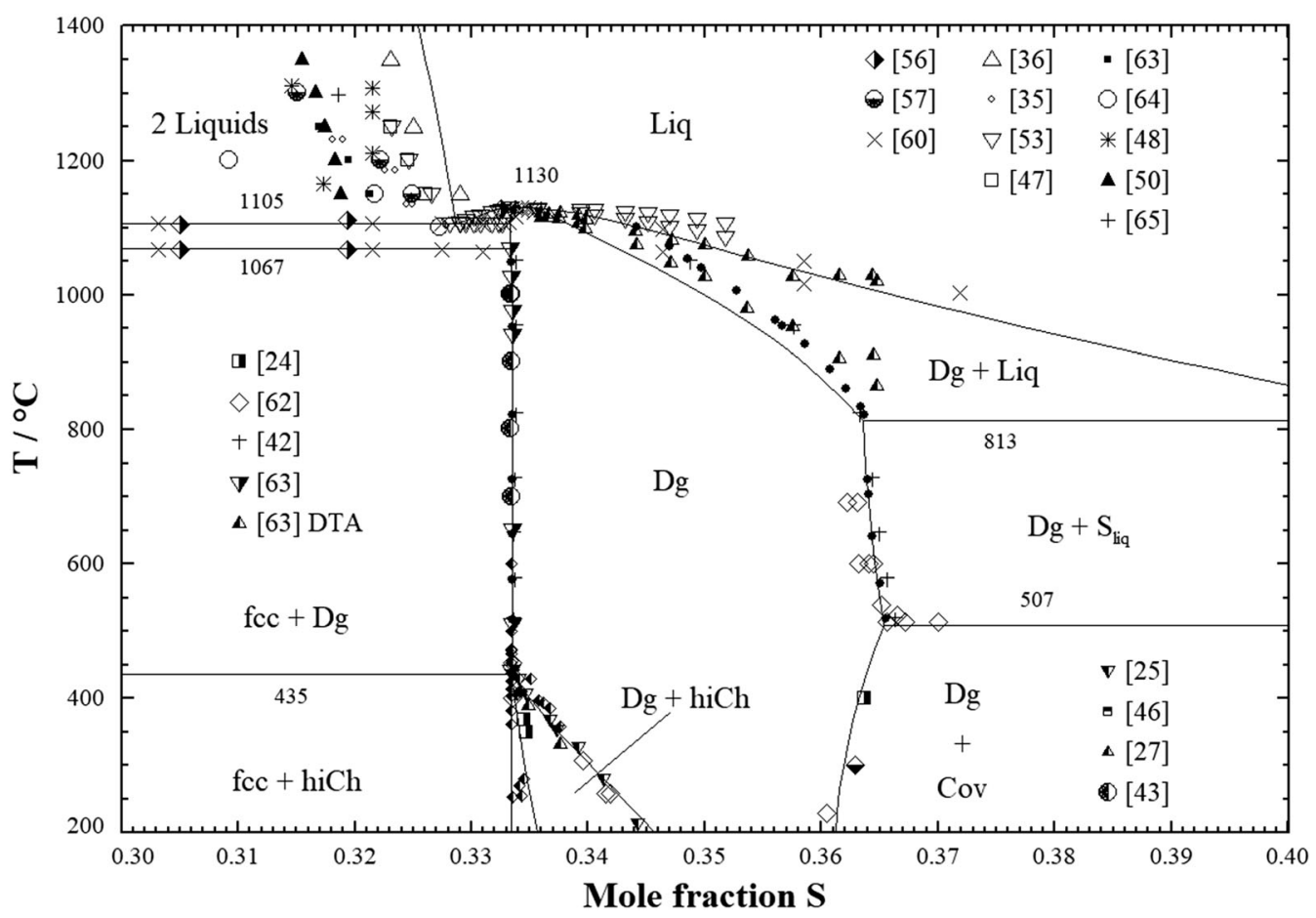

Fig. 3- Calculated partial $T-x$ phase diagram of the binary copper-sulfur system in the composition range between 0.3 and 0.4 mole fraction of sulfur at a total pressure of 1 bar together with the experimental data. $\mathrm{Dg}=$ digenite; fcc $=$ face-centered cubic copper phase; hiCh $=$ high-temperature chalcocite; $\mathrm{Cov}=$ covellite.

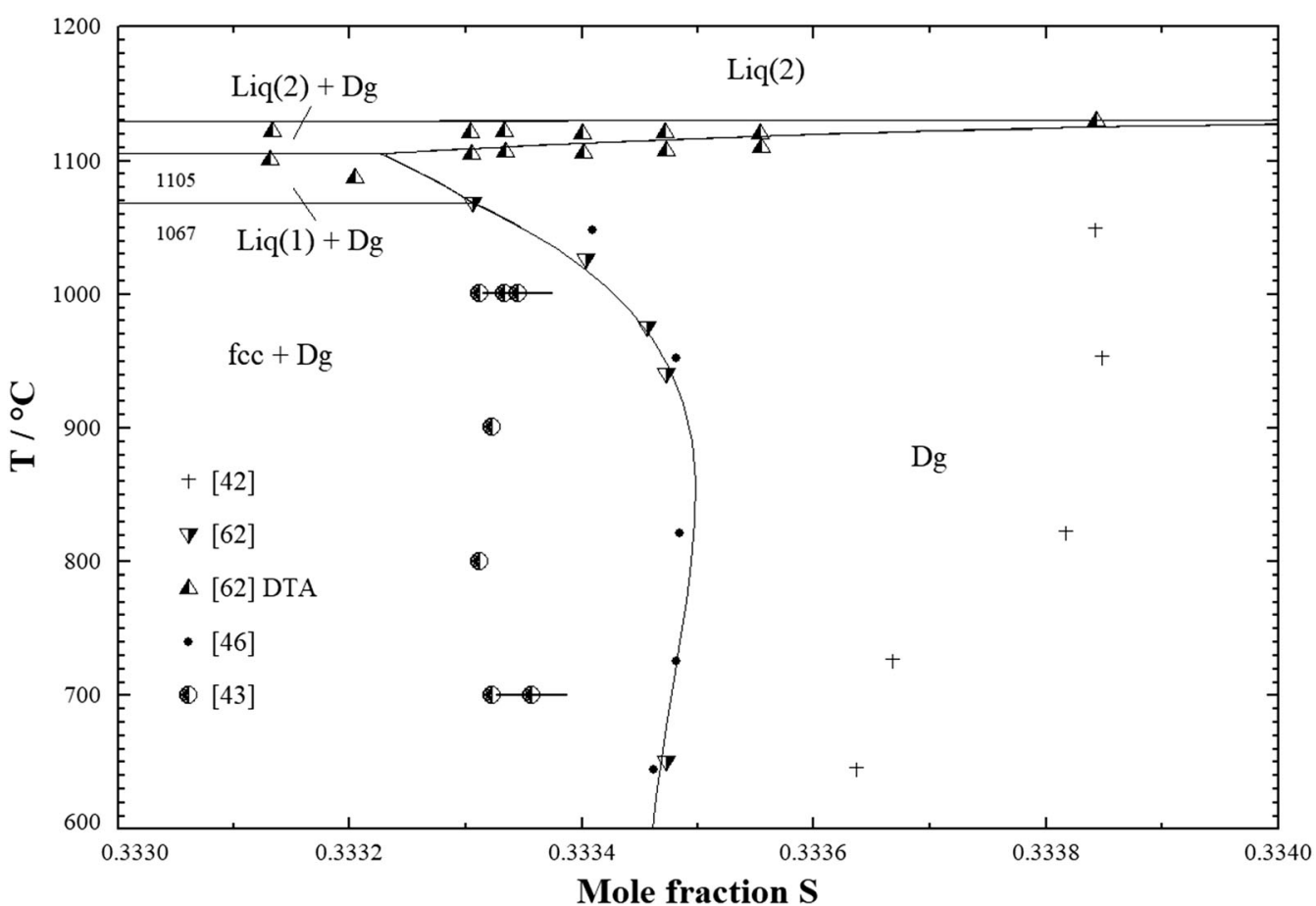

Fig. 4-Calculated partial $T-x$ phase diagram of the binary copper-sulfur system in the composition range around $\mathrm{Cu}_{2} \mathrm{~S}$ at a total pressure of 1 bar together with the experimental data. $\mathrm{Dg}=$ digenite; fcc $=$ face-centered cubic copper phase. 
Table II. Calculated Invariant Equilibria, Comparison with Reviewed and Assessed Data ${ }^{[1,70]}$

\begin{tabular}{|c|c|c|c|c|c|}
\hline Invariant Equilibrium & $T /\left({ }^{\circ} \mathrm{C}\right)$ & Composition/(At. Pct S) & & & Refs. \\
\hline \multirow[t]{2}{*}{$\mathrm{Cu}_{\mathrm{Liq}} / \mathrm{Cu}_{\mathrm{fcc}}$} & \multirow[t]{2}{*}{1084.87} & 0.00 & \multicolumn{2}{|l|}{0.00} & 70 \\
\hline & & 0.00 & 0.00 & & calc. \\
\hline \multirow[t]{2}{*}{$\mathrm{Dg} / \mathrm{Liq}$} & $1130 \pm 2$ & 33.40 & \multicolumn{2}{|l|}{33.40} & 1 \\
\hline & 1130.33 & 33.46 & \multicolumn{2}{|l|}{33.46} & calc. \\
\hline \multirow[t]{2}{*}{$\operatorname{Liq}(1) / \operatorname{Liq}(2) / \operatorname{Dg}$} & 1105.00 & $\sim 2.00$ & -32.90 & 33.31 & 1 \\
\hline & 1105.10 & 1.81 & 32.86 & 33.32 & calc. \\
\hline \multirow[t]{2}{*}{$\mathrm{fcc} / \mathrm{Liq} / \mathrm{Dg}$} & 1067.00 & 0.023 & 1.48 & 33.33 & 1 \\
\hline & 1067.80 & 0.023 & 1.54 & 33.33 & calc. \\
\hline \multirow[t]{2}{*}{$\operatorname{Dg} / \operatorname{Liq}(2) / S_{\text {liq }}$} & 813.00 & $\sim 36.40$ & 40.10 & 99.83 & 1 \\
\hline & 813.31 & 36.35 & 41.56 & 99.49 & calc. \\
\hline \multirow[t]{2}{*}{$\mathrm{Dg} / \mathrm{Cov} / \mathrm{S}_{\text {liq }}$} & $507 \pm 2$ & $36.60 \pm 0.07$ & $50.00 \pm 0.02$ & 99.98 & 1 \\
\hline & 507.37 & 36.53 & 50.00 & 99.97 & calc. \\
\hline \multirow[t]{2}{*}{$\operatorname{Cov} / \mathrm{S}_{\mathrm{liq}} / \mathrm{S}_{\text {monocl. }}$} & 115.22 & 50.00 & 100.00 & 100.00 & 1 \\
\hline & 115.21 & 50.00 & 100.00 & 100.00 & calc. \\
\hline \multirow{2}{*}{$\mathrm{S}_{\mathrm{liq}} / \mathrm{S}_{\text {monocl. }}$} & 115.21 & 100.00 & 100.00 & & 70 \\
\hline & 115.21 & 100.00 & 100.00 & & calc. \\
\hline
\end{tabular}

Table III. Optimized Molar Enthalpies of Melting of the Digenite Solid Solution at Sulfur Mole Fraction of 0.3346 Compared with Experimental $^{[52-55]}$ and Assessed ${ }^{[71,72]}$ Data

\begin{tabular}{lll}
\hline$T_{\text {melt }} /\left({ }^{\circ} \mathrm{C}\right)$ & \multicolumn{1}{c}{$\Delta_{\text {melt }} H / \mathrm{J} \mathrm{mol}^{-1}$} & Refs. \\
\hline & $18,379.31$ & 52 \\
& $23,012.00$ & 71 \\
1129.00 & $11,296.80 \pm 146.44$ & 53 \\
& $11,296.80$ & 54 \\
1128.85 & $9623 \pm 2092$ & 72 \\
1126.85 & $12,844.88$ & 55 \\
1130.33 & $17,486.82$ & calc. \\
\hline
\end{tabular}

magnitude. For both phases, the comparison of the calculation with mutually independent experimental data solely related to either digenite ${ }^{[13]}$ or the liquid phase (see Figures 1(a) through (c)) indicates the plausibility of the performed Gibbs energy modeling. Indeed, several efforts to change the optimized parameters of either the digenite model and/or the liquid phase to lower the calculated enthalpy of melting have resulted in substantial deterioration of the correspondence between the calculation and other experimental data.

\section{B. Complete $T-x$ Phase and $\log p_{S 2}-1 / T$ Diagram}

Since the presented Gibbs energy model describes the thermodynamics of the $\mathrm{Cu}-\mathrm{S}$ liquid phase over the whole composition range, the complete liquidus of the $T-x$ phase diagram from pure copper to pure sulfur can be computed. The thermodynamic optimization of this work is performed consistently with the Gibbs energy models of all $\mathrm{Cu}-\mathrm{S}$ solid phases reported recently. ${ }^{[13,14]}$ Consequently, it is now possible to calculate the complete $T-x$ phase diagram by one set of thermodynamically consistent Gibbs energy parameters of all system phases. Figure 5 shows the complete condensed
$T-x$ phase diagram of the copper-sulfur system from room to liquidus temperatures combining the partial phase diagrams of Figures 2 through 4 with the solid-state phase diagrams from Waldner. ${ }^{[13,14]}$ As no firm experimental information exists for the two miscibility gaps of the liquid phase at elevated temperatures, the corresponding phase boundaries are depicted as dotted lines. For a detailed comparison of experimental data with the calculation of solid-state equilibria as given for solid-liquid equilibria in Figures 2 through 4, the reader is referred to Waldner. ${ }^{[13,14]}$

Another type of phase diagram is given in Figure 6 where two thermodynamic potential quantities are plotted as $\log p_{\mathrm{S} 2}$ vs $1 / T$. The ranges of the $\log p_{\mathrm{S} 2}-$ and $1 / T$-axis are chosen in such a way that all condensed nonvariant three-phase equilibria of the copper-sulfur system (depicted as triple points) are captured in one plot. Calculated two-phase equilibria are shown as solid lines. The two lines representing the two miscibility gaps of the liquid phase are shown as dotted lines since no experimental data exist about their critical temperature and pressure. The correspondence between the majority of experimental data and computation is satisfactory.

However, a detailed analysis of the data given by Preuner and Brockmöller, ${ }^{[31]}$ Allen and Lombard, ${ }^{[32]}$ Dickson et al., ${ }^{[41]}$ Vanyukov et al., ${ }^{[4]} \mathrm{Rau}^{[46]}$ as well as Westrum $^{[51]}$ revealed substantial deviation from the calculated line representing the two-phase equilibria $\mathrm{Dg}+S_{\text {liq. }}$. To elucidate this apparent discrepancy, magnifications of this region are demonstrated in Figures 7(a) and (b). Figure 7(a) shows a $\log \left(p_{\text {tot }} /\right.$ bar $)-$ $1 / T$ plot (solid lines) overlapped with a magnification of the partial condensed $\log \left(p_{\mathrm{S} 2} /\right.$ bar $)-1 / T$ diagram (dotted lines). The solid lines stand for the calculation of the equilibrium total pressure where not only $\mathrm{S}_{2}$ species are considered in the gas phase but also other gaseous sulfur molecules such as $S_{1}$ up to $S_{8}$. These lines merge into the dotted lines of the $\log \left(p_{\mathrm{S} 2} /\right.$ bar $)-1 / T$ diagram at lower 


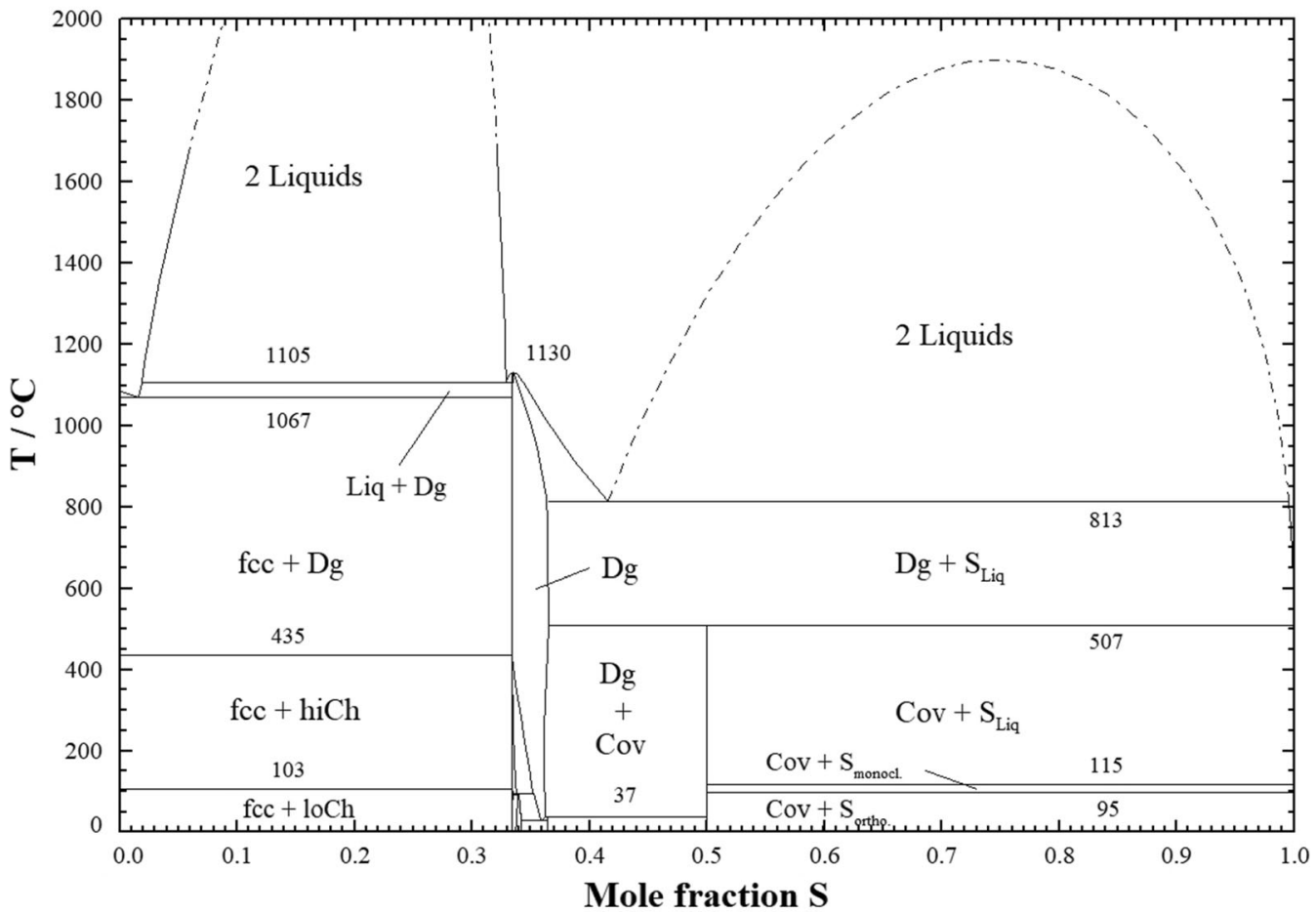

Fig. 5- Calculated condensed $T-x$ phase diagram of the binary copper-sulfur system at a total pressure of 1 bar. For details of low-temperature phase equilibria between 0.3 and 0.4 mole fraction of sulfur, the reader is referred to Waldner. ${ }^{[13,14]} \mathrm{Dg}=$ digenite; fcc $=$ face-centered cubic copper phase; hiCh $=$ high-temperature chalcocite; loCh $=$ low-temperature chalcocite; $\mathrm{Cov}=$ covellite.

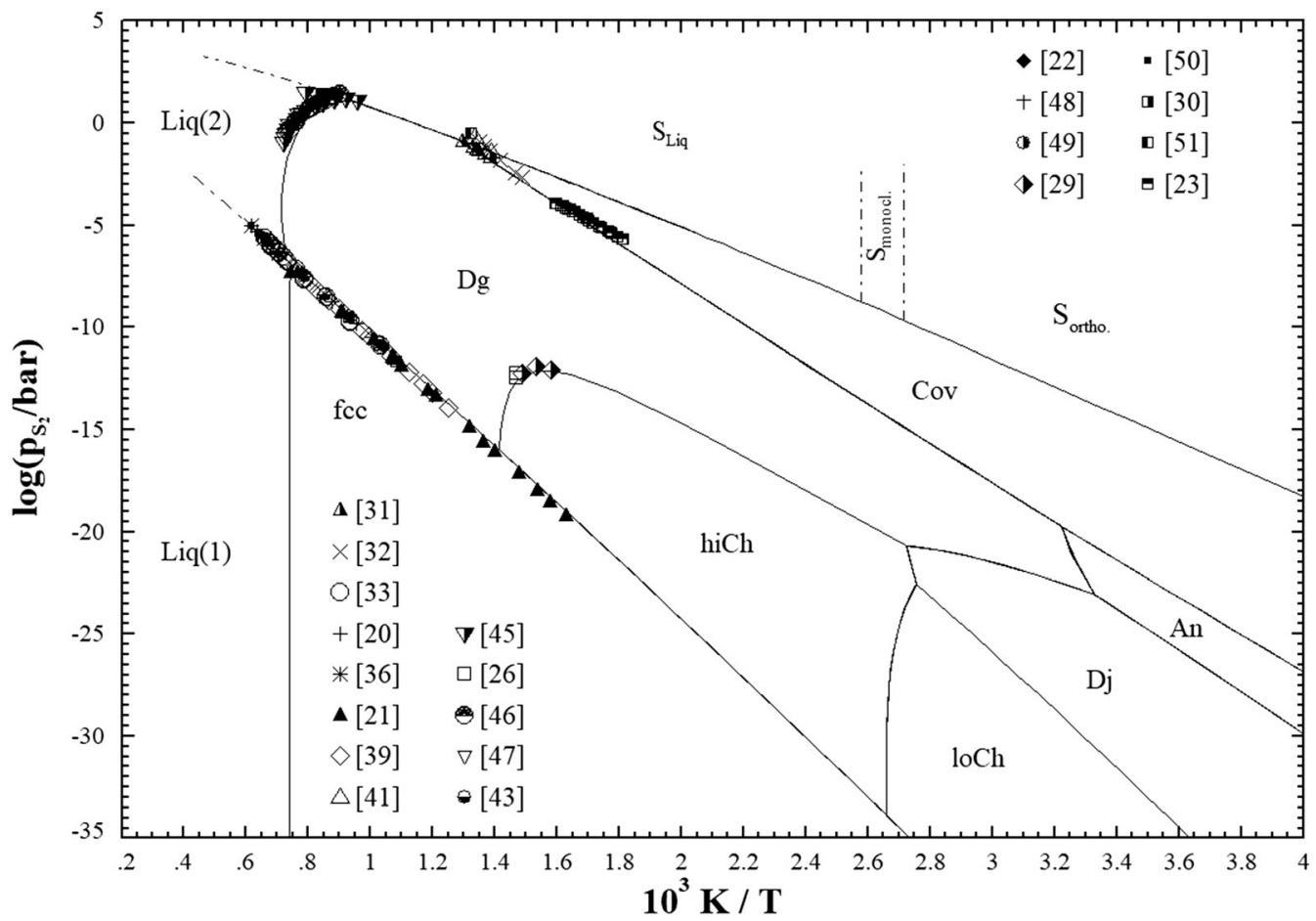

Fig. 6 - Calculated condensed $\log \left(p_{\mathrm{S} 2} /\right.$ bar $)-1 / T$ diagram together with experimental data. $\mathrm{Dg}=$ digenite; fcc $=$ face-centered cubic copper phase; hiCh = high-temperature chalcocite; loCh = low-temperature chalcocite; $\mathrm{An}=$ anilite; $\mathrm{Dj}=$ djurleite; Cov $=$ covellite. 


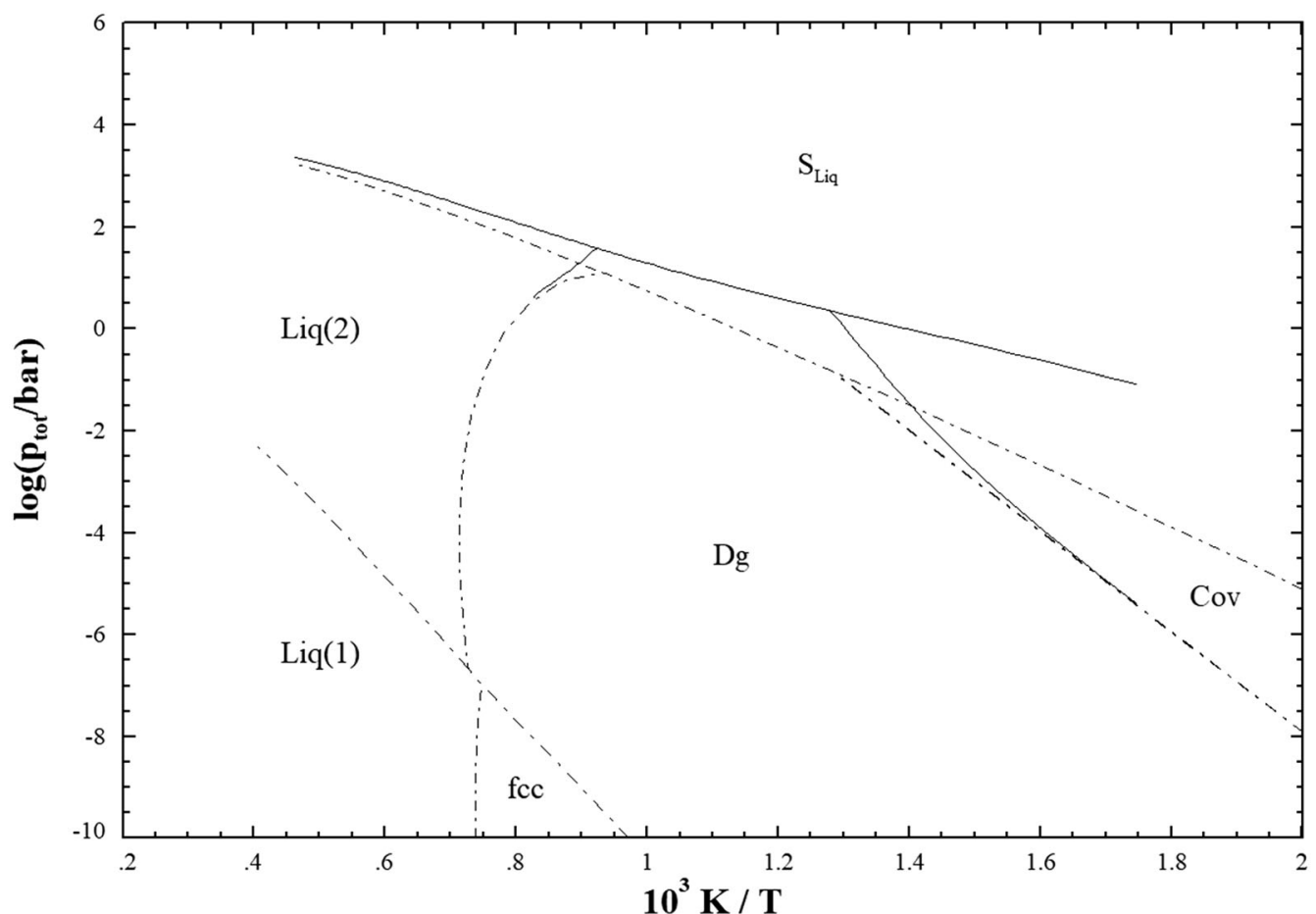

(a)

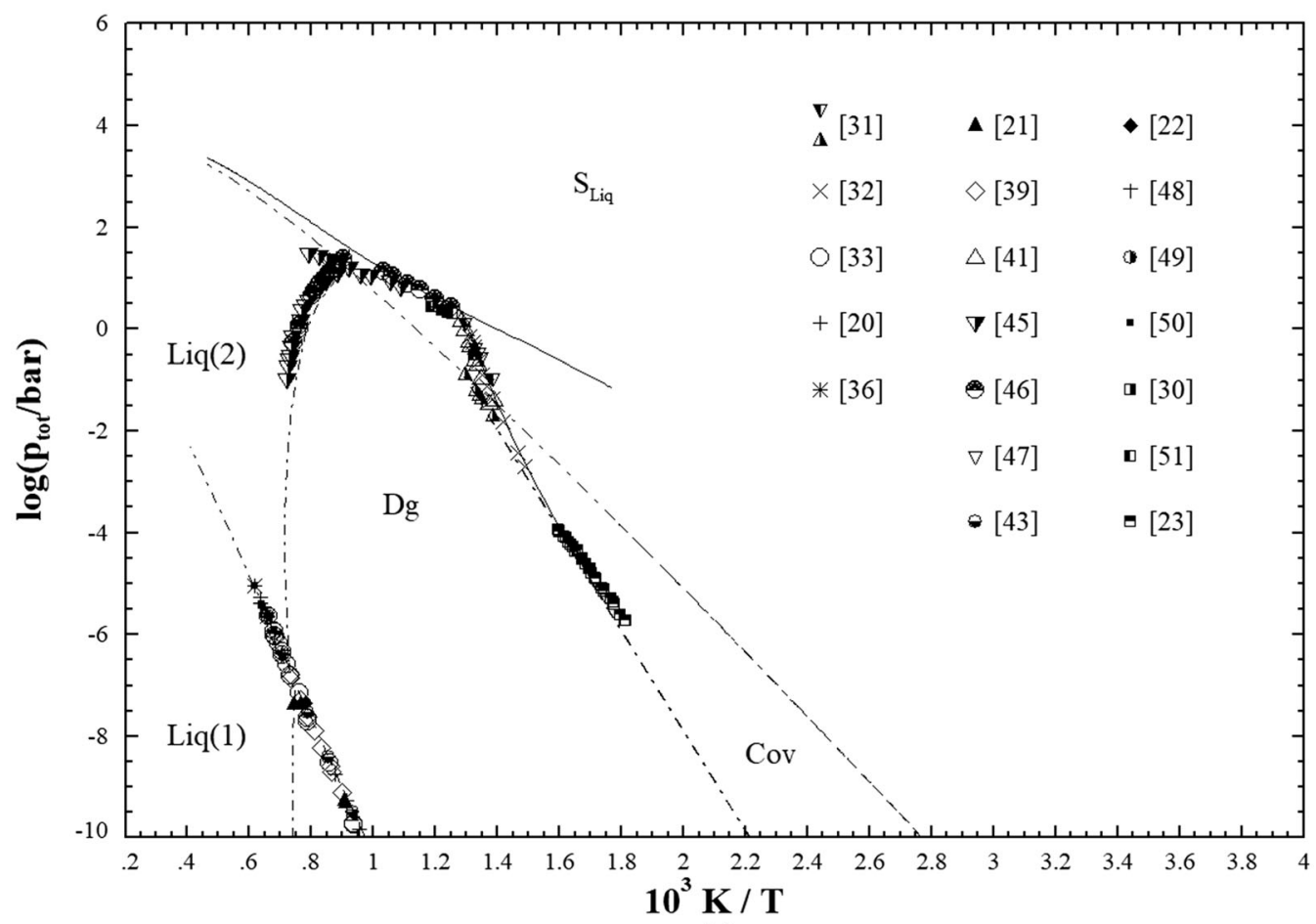

(b)

Fig. 7 - (a) Calculated $\log \left(p_{\text {tot }} /\right.$ bar $)-1 / T$ plot (solid lines) overlapped with magnification of the partial condensed $\log \left(p_{\mathrm{S} 2} / \mathrm{bar}\right)-1 / T$ diagram (dotted lines). $\mathrm{Dg}=$ digenite; fcc $=$ face-centered cubic copper phase; Cov $=$ covellite. $(b)$ Calculated $\log \left(p_{\text {tot }} /\right.$ bar $)-1 / T$ plot $($ solid lines $)$ overlapped with magnification of the partial condensed $\log \left(p_{\mathrm{S} 2} /\right.$ bar $)-1 / T$ diagram (dotted lines) together with experimental data. Dg $=$ digenite; fcc $=$ face-centered cubic copper phase; $\mathrm{Cov}=$ covellite. 
sulfur content [two-phase equilibria $\mathrm{Dg}+\mathrm{Liq}(2)]$ and at elevated temperatures (two-phase equilibria Dg $+\mathrm{Cov}$ ). Both conditions-lower sulfur content and/or elevated temperature-favor the existence of $\mathrm{S}_{2}$ species at the cost of other gaseous species.

In Figure 7(b) experimental data are added for comparison with the computed lines of Figure 7(a). The data from Preuner and Brockmöller ${ }^{[31]}$ (the symbol 'inverted half-filled left triangle' shows these data for the total pressure; the other symbol, 'half-filled right triangle,' stands for the partial pressure of $S_{2}$ ). Allen and Lombard, ${ }^{[32]}$ Dickson et al., ${ }^{[41]}$ Vanyukov et al., ${ }^{[45]}$ $\mathrm{Rau}^{[46]}$ and Westrum ${ }^{[51]}$ can be satisfactorily reproduced by the calculation when a complex gas phase with $S_{1}$ through $\mathrm{S}_{8}$ is taken into account and consequently the total pressure instead of the partial pressure of $S_{2}$ is plotted. This corresponds to the fact that Preuner and Brockmöller, ${ }^{[31]}$ Allen and Lombard, ${ }^{[32]}$ Dickson et al., ${ }^{[1]}$ Vanyukov et al., ${ }^{[45]} \mathrm{Rau}^{[46]}$ and Westrum ${ }^{[51]}$ have carried out vapor pressure measurements in temperature/composition regimes where the total pressure cannot be interpreted as the pressure of gaseous $\mathrm{S}_{2}$ only.

\section{CONCLUSIONS}

Gibbs energy modeling of the copper-sulfur liquid phase using the extended modified quasichemical model results in a set of six parameters by which a large stock of experimental thermodynamic data can be reproduced. Together with recently reported Gibbs energies on all $\mathrm{Cu}-\mathrm{S}$ solid phases, the complete $T-x$ phase diagram at 1 bar total pressure as well as for the first time the $\log \left(p_{\mathrm{S} 2} /\right.$ bar $)-1 / T$ diagram is calculated. Compared with numerous experimental data with equilibria calculations up to now unobtainable insights on phase relations in certain temperature and composition regimes may be given. A test extension of the model to the $\mathrm{Cu}-\mathrm{Fe}-\mathrm{S}$ ternary melt allows promising predictions of solid-liquid equilibria at elevated temperatures. The obtained optimization is seen as part of a comprehensive thermodynamic multicomponent/-phase database for metal-sulfur systems.

\section{ACKNOWLEDGMENTS}

Open Access funding provided by the Montanuniversitaet Leoben.

\section{OPEN ACCESS}

This article is licensed under a Creative Commons Attribution 4.0 International License, which permits use, sharing, adaptation, distribution and reproduction in any medium or format, as long as you give appropriate credit to the original author(s) and the source, provide a link to the Creative Commons licence, and indicate if changes were made. The images or other third party material in this article are included in the article's Creative Commons licence, unless indicated otherwise in a credit line to the material. If material is not included in the article's Creative Commons licence and your intended use is not permitted by statutory regulation or exceeds the permitted use, you will need to obtain permission directly from the copyright holder. To view a copy of this licence, visit http://creativec ommons.org/licenses/by/4.0/.

\section{REFERENCES}

1. D.J. Chakrabarti and D.E. Laughlin: Phase Diagrams of Binary Copper Alloys, P.R. Subramanian, ed., ASM International, Materials Park, OH, 1994, pp. 355-71.

2. H.H. Kellogg: Can. Metall. Quart., 1969, vol. 8 (1), pp. 3-23.

3. H.H. Kellogg: Physical Chemistry in Metallurgy, R.M. Fisher, R.A. Oriana, and E.T. Turkdogan, eds., US Steel Research, Monroeville, PA, 1976, pp. 49-68.

4. J.M. Larrain, S.L. Lee, and H.H. Kellogg: Can. Metall. Q., 1979, vol. 18 (4), pp. 395-400.

5. R.C. Sharma and Y.A. Chang: Metall. Trans., 1980, vol. 11B, pp. $575-83$.

6. A.T. Dinsdale, T.G. Chart, T.I. Barry, and J.R. Taylor: High Temp. High Press., 1982, vol. 14, pp. 633-40.

7. F. Kongoli, Y. Dessureault, and A.D. Pelton: Metall. Mater. Trans. B, 1998, vol. 29B, pp. 591-601.

8. S.A. Degterov and A.D. Pelton: Metall. Mater. Trans. B, 1999, vol. 30B, pp. 661-69.

9. P. Waldner and A.D. Pelton: Unpublished research, École Polytechnique de Montreal, Montreal, QC, Canada, 2006.

10. B.J. Lee, B. Sundman, S.I.I. Kim, and K.G. Chin: ISIJ Int., 2007, vol. 47(1), pp. 163-71.

11. D. Shishin and S.A. Decterov: CALPHAD, 2012, vol. 38, pp. 5970.

12. T. Jantzen, K. Hack, E. Yazhenskikh, and M. Mueller: $C A L-$ PHAD, 2017, vol. 56, pp. 270-85.

13. P. Waldner: Metall. Mater. Trans. B, 2017, vol. 48B (4), pp. 215766.

14. P. Waldner: J. Phase Equilib. Diff., 2018, vol. 39, pp. 810-19.

15. P. Waldner and A.D. Pelton: J. Phase Equilib. Differ., 2005, vol. 26, pp. 23-38.

16. P. Waldner and A.D. Pelton: Z. Metal., 2004, vol. 95, pp. 672-81.

17. P. Waldner and W. Sitte: Int. J. Mat. Res. (formerly Z. Metallkd.), 2011, vol. 102, pp. 1216-25.

18. P. Waldner and A.D. Pelton: Metall. Mater. Trans. B, 2004, vol. 35B, pp. 897-907.

19. P. Waldner: Metall. Mater. Trans. A, 2014, vol. 45B, pp. 798-814.

20. K. Sudo: Sci. Rep. Res. Inst., Tohoku Univ., 1950, vol. A2, pp. $13-518$

21. A.A. Brooks: Am. Chem. Soc. J., 1953, vol. 75, pp. 2464-67.

22. K. Sadakane, M. Kawakami, and S. Kazuhiro: Tetsu to Hagane, 1977, vol. 69, pp. 44-52.

23. B. Brunetti, V. Piacente, and P. Scardala: J. Alloys Compd., 1994, vol. 206, pp. 113-19.

24. V. Wehefritz: Z. Phys. Chem. NF, 1960, vol. 26, pp. 339-58.

25. H. Luquet, F. Guastavino, J. Bougnot, and J.C. Vaissiere: Mater. Res. Bull., 1972, vol. 7, pp. 955-62.

26. R. Peronne, D. Balesdent, and J. Rilling: Bull. Soc. Chim., 1972, vol. 2, pp. 457-63.

27. A. Dumon, A. Lichanot, and S. Gromb: J. Chim. Phys., 1974, vol. 71 (3), pp. 407-14.

28. N. Nagamori: Metall. Trans. B, 1976, vol. 7B, pp. 67-80.

29. R. Peronne and D. Balesdent: J. Chem. Thermodyn., 1983, vol. 15, pp. 295-303.

30. G. Sick and K. Schwerdtfeger: Met. Trans. B, 1984, vol. 15B, pp. 736-39. 
31. G. Preuner and I. Brockmöller: Z. Phys. Chem., 1913, vol. 81, pp. $129-70$

32. E.T. Allen and R.H. Lombard: Am. J. Sci., 1917, vol. 43, pp. 175 95.

33. E.M. Cox, M.C. Bachelder, N.H. Nachtrieb, and A.S. Skapski: $J$. Metals Trans., 1949, vol. 1, pp. 27-31.

34. K. Sudo: Sci. Rep. Res. Inst., Tohoku Univ., 1950, vol. A2, pp. 519-30.

35. K. Sudo: Bull. Res. Inst. Mineral Dress. Metall., 1954, vol. 10, pp. $45-56$.

36. R. Schuhmann (JR.) and O.W. Moles: Trans. AIME, 1951, vol. 191, pp. $235-41$.

37. K. Hirakoso, T. Tanaka, and K. Watanabe: Mem. Fac. Eng. Hokkaido Univ., 1952, vol. 9(2), pp. 125-32.

38. T. Yagihashi: Nippon Kinzoku Gakkai Shi., 1953, vol. 17 (10), pp. $483-87$.

39. F.D. Richardson and J.E. Antill: Trans. Faraday Soc., 1955 , vol. 51, pp. 22-33.

40. C.B. Alcock: Int. J. Appl. Radiat. Isotop., 1958, vol. 3, pp. 135-42.

41. F.W. Dickson, L.D. Shields, and G.C. Kennedy: Econ. Geol., 1962, vol. 57 (7), pp. 1021-30.

42. H. Rau: J. Phys. Chem. Solids, 1967, vol. 28, pp. 903-16.

43. M. Nagamori and T. Rosenqvist: Metal. Trans., 1970, vol. 1, pp. 329-30.

44. C.W. Bale and J.M. Toguri: J. Therm. Anal., 1971, vol. 3(2), pp. $153-67$.

45. A.V. Vanyukov, V.P. Bystrov, and V.A. Snurnikova: Sov. J. Non-ferrous Metall., 1971, vol. 11(11), pp. 11-14.

46. H. Rau: J. Phys. Chem. Solids, 1974, vol. 35, pp. 1415-24.

47. C.W. Bale and J.M. Toguri: Can. Metall. Quart., 1976, vol. 15 (4), pp. $305-18$

48. V.-P. Judin and M. Eerola: Scand. J. Metall., 1979, vol. 8 (3), pp. 128-32.

49. J. Koh and A. Yazawa: Bull. Res. Inst. Mineral Dress. Metall. Tohoku Univ. Sendai, 1982, vol. 38(2), pp. 107-18.

50. J. Niemelä and P. Taskinen: Scand. J. Metall., 1984, vol. 13 (6), pp. $382-90$.

51. J.R. Westrum, S. Stølen, and F. Grønvold: J. Chem. Thermodyn., 1987, vol. 19, pp. 1199-1208.

52. K. Friedrich: Metall. Erz, 1914, vol. 11, pp. 161-67.

53. F. Johannsen and H. Vollmer: Z. Erzmetall., 1960, vol. 13(7), pp. 313-22.
54. A.Y. Mendelevich, A.N. Krestovnikov, and V.M. Glazov: Russ. J. Phys. Chem., 1969, vol. 43 (12), pp. 1723-24.

55. M.J. Ferrante, J.M. Stuve, and L.B. Pankratz: High Temp. Sci., 1981, vol. 14 (2), pp. 77-90.

56. E. Heyn and O. Bauer: Metallurgie, 1906, vol. 3, pp. 73-86.

57. K. Friedrich and M. Waehlert: Metall. Erz, 1913, vol. 10 (30), pp. 976-79.

58. K. Bornemann and K. Wagenmann: Ferrum, 1914, vol. 11, pp. 289-314.

59. C.S. Smith: Trans. AIME, 1938, vol. 128, pp. 325-36.

60. E. Jensen: Avhandl. Norske Videnskaps Akad. Oslo I. Mat. Nat. Kl., 1947, vol. 6, pp. 3-14.

61. E.H. Roseboom: Econ. Geol., 1966, vol. 61, pp. 641-72.

62. W.R. Cook: Ph.D. Thesis, Case Western Reserve University, Cleveland OH, 1971.

63. J. Schmiedl, V. Repčák, and Š. Cempa: Trans. Inst. Min. Metall. C, 1977, vol. 86, pp. C88-C91

64. M. Moulkl and J. Osterwald: Z. Metall., 1979, vol. 70 (12), pp. $808-10$.

65. V.M. Glazov, S.G. Kim, and G.K. Mambeterzina: Russ. J. Phys. Chem., 1992, vol. 66 (9), pp. 1349-52.

66. A.D. Pelton and M. Blander: Metall. Trans. B, 1986, vol. 17B, pp. 805-15.

67. A.D. Pelton, S.A. Degterov, G. Eriksson, C. Robelin, and Y. Dessureault: Metall. Trans. B, 2000, vol. 31B, pp. 651-59.

68. A.T. Dinsdale: CALPHAD, 1991, vol. 15, pp. 317-425.

69. C.W. Bale, E. Belisle, P. Chartrand, S.A. Degterov, G. Eriksson, K. Hack, I.-H. Jung, Y.-B. Kang, J. Melançon, A.D. Pelton, C. Robelin, and S. Petersen: CALPHAD, 2009, vol. 33 (2), pp. 295311.

70. M.W. Chase Jr., C.A. Davies Jr., J.R. Downey Jr., D.J. Frurip, R.A. McDonald, and A.N. Syverud, JANAF Thermochemical Tables, 3rd ed., J. Phys. Chem. Ref. Data, Supplement No. 1, 1985, vol. 14, pp. 1774-77.

71. K.K. Kelley: Bull. U.S. Bur. Mines 393, US Government Printing Office, 1936.

72. K.C. Mills: Thermodynamic Data for Sulphides, Selenides and Tellurides, NPL, Teddington, 1974, p. 237.

Publisher's Note Springer Nature remains neutral with regard to jurisdictional claims in published maps and institutional affiliations. 